\title{
Listening to Frances R. Aparicio: Critical interventions in the study of popular culture
}

\author{
Jillian M. Báez ${ }^{1}$
}

Published online: 23 April 2020

(c) Springer Nature Limited 2020

I first encountered Frances Aparicio's scholarship in Angharad Valdivia's graduate course on transnational feminisms when we were assigned her book Listening to Salsa: Gender, Latin Popular Music, and Puerto Rican Cultures (1998). Growing up Puerto Rican in New York City, I listened largely to pop music, the growing hiphop music playing on the streets, R\&B (particularly Stevie Wonder), freestyle dance music, many artists who were New York Puerto Ricans like Lisa Lisa and Safire, and salsa music. With salsa as the heartbeat of Puerto Rican New York, the musical genre loomed large in the background of my everyday life in a Puerto Rican enclave in the 1980s and 1990s. I was fortunate enough to have seen some of the greatest salseros, such as Tito Puente, Eddie Palmieri, Willie Colon, and Celia Cruz, play live locally in New York City as a young girl and teenager. In fact, I looked toward the Nuyorican salseros, like Puente and Palmieri, as a model for a life I could aspire to in the future. Mixing sounds and lyrics from across the Americas and touring globally, these salseros provided a template for navigating my cultural and linguistic hybridity as a Puerto Rican in the diaspora. They also exemplified the possibilities that might be explored outside of my Puerto Rican enclave, particularly in terms of travel and collaboration with other artists. I did sorely observe, however, that aside from Celia Cruz, La Lupe, and later La India, women were not central to the larger narrative of salsa except as (hetero)sexual and romantic partners.

Women's absence in the dominant discourses surrounding salsa was momentarily interrupted with the release of La India's best-selling album Dicen Que Soy in 1994. La India was born Linda Caballero in Rio Piedras, Puerto Rico, and raised in the Bronx. She took on the stage name "La India" based on her indigenous physical features, such as her brown skin and long black hair (Obejas 1997). ${ }^{1}$ Dicen Que Soy was La India's third album; her first was a freestyle album

\footnotetext{
1 Aparicio (2002) notes that La India's stage name is a "racial signifier" that at once harkens to the contemporary Taino revival movement in the Spanish Caribbean yet also can eclipse claims to blackness as a central part of Puerto Rican identity.
}

Jillian M. Báez

jb6377@hunter.cuny.edu

1 Hunter College, The City University of New York (CUNY), New York, NY, USA 
titled Breaking Night (1990), and her second (and debut salsa album), Llegó La India (1992), featured and was produced by seasoned salsa and Latin jazz musician Eddie Palmieri. "Ese Hombre," a cover of Spanish pop singer Rocío Jurado's hit, was the breakout success from Dicen Que Soy. The lyrics are written through the perspective of an assumed heterosexual woman who exposes how deceptive her male lover is. She sings,

Ese hombre que tu ves ahí

Que parece tan galante

Tan atento y arrogante

Lo conozco como a mi

Ese hombre que tu ves ahi

Que aparenta ser divino

Tan amable y efusivo

Solo sabe hacer sufrir

Es un gran necio

Un estúpido engreído

Egoísta y caprichoso

Un payaso vanidoso

(That man that you see right there

That seems so gallant

So thoughtful and arrogant

I know him for myself

This man that you see right there

That seems so divine

So lovely and warm

Only knows how to cause suffering

He's a big idiot

A stupid bigheaded

Egoist and he's capricious

A vain clown)

La India, in full vibrato, throws a litany of criticism on "this man," and by the end of the song the chorus and refrain focus on how she was "tricked" by him and now wants to expose the truth about him. One could read her as a scorned woman, as Latin American female artists are often described by music critics, or one could read the lyrics and her vocal performance of the song as pushing against patriarchy and the silencing of women. The former is how I interpreted the song as a teen who largely saw women in my community as martyrs and/or domestic violence survivors who lived in silence within gender norms inflected by Catholic and Pentecostal traditions. La India's "Ese Hombre" certainly disrupted my own internalized sense of Latina womanhood. Reading Aparicio's Listening to Salsa, and her later work on La India, La Lupe and Celia Cruz (Aparicio 2003), offered me a nuanced and sophisticated language with which to understand and express my conflicted relationship with salsa, particularly in terms of gendered politics 
and feminist audience reception. Frances also developed theoretical frameworks and methodologies that would later heavily influence my scholarship on popular media and Latina/o/x audiences.

When "Ese Hombre" was released on the radio, it was a chart-topper and solidified her as the "Princess of salsa" (after Celia Cruz as the "Queen of salsa"). However, I also remember some of the reception of La India, particularly in reference to this song, to be conflicted. Some Latina/o listeners expressed discomfort with the song and felt that she was "screaming" or forcing herself onto her listeners via her strong vibrato. La India was subverting the 1980s genre of salsa romántica (romantic salsa) or, as Aparicio (1998) calls it, salsa lite, which was dominated by male singers singing about male heterosexual desire. The tone of salsa romántica-both vocal and instrumental-was also light. Although La India's "Ese Hombre" (and the rest of the songs on this album) musically builds on salsa romantica in sound, La India pushed the racial and gendered boundaries of the genre. La India's presence as a brown woman from the diaspora who smokes a cigar, paired with her assertive vocals and lyrics, were groundbreaking in both her recorded and live performances. ${ }^{2}$

La India was the first salsa artist with whom I did not have to engage in what Frances calls "rewriting pleasure," where listeners rewrite the lyrics in their minds to better fit within their perspectives and sense of self (Aparicio 1998). "Rewriting pleasure" was a tactic audiences deployed to fill in the silences and gaps in patriarchal cultural production. La India's music would be a gateway for me into other forms of Latina/o/x feminist music and other forms of protest music (e.g., La Santa Cecilia, La Sista, and La Krudas). When I was collecting data for my book on Latina media audiences (Báez 2018), La India appeared in the backdrop of some of the interviews. La India was one of the few long-standing figures of Latina womanhood in popular music, but did not fit neatly into the ways that Latinas are represented in both English-language and Spanish-language media. As a full bodied, brown, Santeria practicing, and cigar-smoking woman with a fierce voice and presence, La India herself has struggled to find her place within Latina/o/x popular culture. For example, La India told the Associated Press she planned to lose weight and return to the stage looking like "una Barbie" ("a Barbie doll") (Associated Press 2008). Years later La India publicly proclaimed herself a feminist (Jottar 2016). At first glance these statements might seem paradoxical. However, one of Frances's common dichos to her students is that the work we do as cultural critics is to tease out the contradictions. The aim of studying popular culture is not simply to judge whether a text or icon is "positive" or "negative," but instead flesh out the ways in which all our lives are a result of constrained agency.

To be sure, La India is an important icon in expanding the contours of Latina womanhood within Latin American and US Latina/o/x popular music, a point heavily emphasized in Aparicio's work on feminist genealogies in Latin American and Caribbean popular music. I applied this methodology to my analysis of Puerto Rican reggaetón artist Ivy Queen in my first publication “"En mi imperio': Competing

\footnotetext{
2 See Durno and Washburne (2002) for a more in-depth analysis of La India's gender-bending performance style.
} 
Discourses of Agency in Ivy Queen's Reggaetón” (Báez 2006). In the essay, I place Ivy Queen within a feminist genealogy of reggaetón, a genre that remains maledominated in terms of production and content. Aparicio (2002) notes that it is uncommon for women to be producers of Latin(a/o/x) American ${ }^{3}$ music and that, instead, they are often relegated to the realms of dance and consumption.

Aparicio's scholarship on the gendered politics in salsa also paved a way for me to understand Latina/o/x audiences. Listening to Salsa not only examined the content of popular music, but also took Latina audiences seriously as worthy of rigorous scholarly attention. Within cultural studies, research on reception in the 1980s and 1990s did not include scholarship on Latina/o/x audiences. Aparicio employed an intersectional approach to studying Latina audiences, taking note of issues of race, ethnicity, nation, and gender, at a time when this approach was considered experimental in both literary and media studies. Aparicio's attention to Latina listeners as what Stuart Hall (1980) calls "producers of meaning" heavily informed my own development as a scholar of Latina/o media reception. In particular, my book In Search of Belonging: Latinas, Media, and Citizenship (Báez 2018) builds on and extends Frances's germinal work in Listening to Salsa, exploring how Latina audiences use both English- and Spanish-language media as a gauge to measure their place within the nation.

Dr. Aparicio endowed Latina/o studies with a tremendous legacy that is intertwined with her contributions to cultural studies, media studies, and women's and gender studies, among other fields. She pushed scholars to not only take Latin(a/o/x) popular culture texts seriously as a site of analysis, but also to examine Latina audiences as sophisticated and complex interlocutors. Her earlier work on popular music exemplifies this (Aparicio 1998, 1999, 2002; Aparicio et al. 2003), as also does her work on media celebrities and texts, such as her often-cited work on Jennifer Lopez as Selena (2003), analysis of the symbolic and material significance of the Puerto Rican flag burning episode of Seinfeld (2007), and her most recent work on the cultural politics of salsa icon Marc Anthony (Aparicio 2017). I thank Frances for paving the way for so many scholars, like myself, to bravely pursue the intersections of popular culture, gender, and Latinidad across various registers.

\section{References}

Aparicio, F.R. 1998. Listening to Salsa: Gender, Latin Popular Music, and Puerto Rican Cultures. Hanover, NH: University Press of New England.

Aparicio, F.R. 1999. The Blackness of Sugar: Celia Cruz and the Performance of (Trans)nationalism. Cultural Studies 13 (2): 223-236.

Aparicio, F.R. 2002. La Lupe, La India, and Celia: Toward a Feminist Genealogy of Salsa Music. In Situating Salsa: Global Markets and Local Meanings in Latin Popular Music, ed. Lise Waxer, 135-160. New York: Routledge.

\footnotetext{
3 I build on Cepeda's (2010) use of "Latin(o) American" here to refer to the music produced across the Americas.
} 
Aparicio, F.R. 2003. Jennifer as Selena: Rethinking Latinidad in Media and Popular Culture. Latino Studies 1 (1): 90-105.

Aparicio, F.R. 2007. Exposed Bodies: Media and US Puerto Ricans in Public Space. In None of the Above: Puerto Ricans in the Global Era, ed. Frances Negrón-Muntaner, 165-179. New York: Palgrave.

Aparicio, F.R. 2017. Sounding the Image and Imaging the Sound: Marc Anthony 30 and Critical Salsa Romántica. In Sound, Image, and National Imaginary in the Construction of Latin/o American Identities, ed. H. Hernández L'Hoeste and P. Vila, 207-220. Lanham, MD: Lexington Books.

Aparicio, F.R., C.F. Jáquez, and M. E. Cepeda, (eds.). 2003. Musical Migrations: Transnationalism and Cultural Hybridity in Latina/o America, vol. 1. London: Palgrave Macmillan.

Associated Press. 2008. La India anuncia nuevo disco y gira internacional. Retrieved 2 October from https ://advance-lexis-com.proxy.wexler.hunter.cuny.edu/api/document?collection=news\&id=urn:conte ntItem:4TKF-FD70-TXJT-91H7-00000-00\&context=1516831.

Báez, J.M. 2006. "En mi imperio": Competing Discourses of Identity in Ivy Queen's Reggaetón. CENTRO: Journal of the Center for Puerto Rican Studies 18 (2): 62-81.

Báez, J.M. 2018. In Search of Belonging: Latinas, Media, and Citizenship. Latinos in Chicago and the Midwest Series. Urbana: University of Illinois Press.

Cepeda, M.E. 2010. Musical ImagiNation: U.S.-Colombian Identity and the Latin Music Boom. New York: New York University Press.

Durno, M., and C. Washburne. 2002. Masquerading Machismo: La India and the Staging of Chusmería on the Salsa Scene. Women and Performance: A Journal of Feminist Theory 12 (2): 139-156.

Jottar, B. 2016. La India and Her Feminism: An Exclusive Video Interview. Centro Voices, May 23.https ://centropr.hunter.cuny.edu/centrovoices/arts-culture/la-india-and-her-feminism-exclusive-video -interview.

Hall, S. 1980. Encoding/Decoding. In Culture, Media, Language: Working Papers in Cultural Studies, 1982-79, ed. Stuart Hall, Dorothy Hobson, Andrew Lowe, and Paul Willis, 128-138. London: Hutchinson.

Obejas, A. 1997. La India: She Adds a Feminist Fillip to Salsa's Macho Beat. Chicago Tribune, 31 March: Tempo 1.

Publisher's Note Springer Nature remains neutral with regard to jurisdictional claims in published maps and institutional affiliations.

Jillian M. Báez is Associate Professor of Africana and Puerto Rican/Latino Studies at Hunter College and Affiliate Faculty in Women's and Gender Studies at the CUNY Graduate Center. She is the author of In Search of Belonging: Latinas, Media, and Citizenship (University of Illinois Press, 2018). 